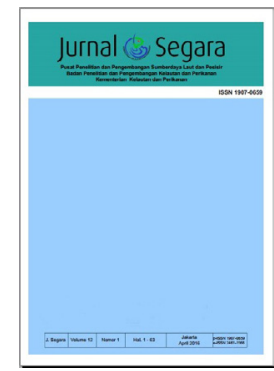

JURNAL SEGARA

http://ejournal-balitbang.kkp.go.id/index.php/segara

ISSN : 1907-0659

e-ISSN : 2461-1166

Nomor Akreditasi: 766/AU3/P2MI-LIPI/10/2016

\title{
DAMPAK PERUBAHAN PENGGUNAAN LAHAN TERHADAP KONDISI PADANG LAMUN DI PERAIRAN TIMUR PULAU BINTAN KEPULAUAN RIAU
}

\section{THE IMPACT OF LAND USES CHANGES \\ TOWARD THE SEAGRASS CONDITION \\ IN THE EAST SEA WATERS OF BINTAN ISLAND RIAU ARCHIPELAGO}

\author{
Indarto Happy Supriyadi, Ricky Rositasari \& Marindah Yulia Iswari \\ Pusat Penelitian Oseanografi-Lembaga IImu Pengetahuan Indonesia \\ JIn. Pasir Putih No. 1 Ancol Timur Jakarta Utara
}

Diterima: 13 Januari 2017; Selesai Perbaikan: 2 Februari 2018; Disetujui Setelah Perbaikan: 30 Maret 2018

\begin{abstract}
ABSTRAK
Padang lamun memiliki peran penting sebagai sumber utama produktivitas primer atau penghasil bahan organik, habitat untuk berbagai biota, tempat asuhan, tempat memijah, sumber makanan bagi biota langka dan penyokong keanekaragaman jenis-jenis biota laut serta bernilai ekonomis dari jasa ekosistem lamun. Aktivitas pembangunan di wilayah pesisir yang terus meningkat telah mengakibatkan kerusakan padang lamun di perairan timur pulau Bintan. Saat ini kajian terbaru terkait dengan kondisi lamun belum tersedia. Kajian ini dilakukan pada Mei dan September (2015-2016) dengan tujuan untuk mengetahui dampak perubahan tutupan lahan terhadap kondisi lamun di perairan timur pulau Bintan. Kondisi lamun ditentukan berdasarkan persentase tutupan lamun. Analisis perubahan penggunaan lahan menggunakan perangkat lunak ENVI 5.1 dan ArcGIS 10.1. Pengukuran debit sungai dan penanganan sampel air dilakukan di lapangan dan laboratorium P2O-LIPI Jakarta. Hasil penelitian menunjukkan bahwa perubahan penggunaan lahan menjadi lahan terbuka, perkebunan dan semak belukar pada DAS Kawal telah memberikan dampak menurunnya kondisi lamun khususnya di sekitar muara Sungai Kawal. Secara umum kondisi lamun di perairan timur Pulau Bintan menurun ditunjukkan dengan persentase tutupan lamun yaitu $46 \%$ (2006) dan 41 \% (2015). Dalam penelitian ini ditemukan tujuh spesies lamun, antara lain Enhalus acoroides, Thalassia hemprichii, Cymodocea rotundata, Cymodocea serrulata, Halophila ovalis, Halodule uninervis dan Syringodium isoetifolium.
\end{abstract}

Kata kunci : Perubahan lingkungan, keanekaragaman, kondisi lamun.

\section{ABSTRACT}

Seagrass beds play important role as the main sources of primary productivity of organic matter, habitat for various biota, nursery, spawning, feeding ground for endangered species, and supporting a high diversity of the species of marine biota and have an economic value of ecosystem services of seagrass. Development activities in coastal areas continue to increase which caused damage to seagrass in the East waters of Bintan island. Currently the study related to the condition of seagrass in the East waters of Bintan island is still not yet available. This study was done on May and September 2015-2016 and the purpose to know the changes impact of the land use toward seagrass condition at the east sea waters of Bintan Island. The seagrass condition determined based on percentage of the seagrass cover. The change of land use analyzed using software of ENVI 5.1and ArcGIS 10.1. River discharges and water samples are measured using 'reading current meter' and analyzed at the Research Center of Oceanography (RCO)-Laboratory of Indonesian Institute of Sciences (LIPI) Jakarta. The result of research showed that the changes of land use as open land, plantation and scrub at the Watershed Area (DAS) has given to the impact of the declining conditions of seagrass especially around the river estuary (Kawal). In general the condition of seagrass in the east sea waters of Bintan Island declining that showed by the percentage of seagrass cover are $46 \%$ (2006) and $41 \%$ (2015). This study found seven species namely Enhalus acoroides, Thalassia hemprichii, Cymodocea rotundata, Cymodocea serrulata, Halophila ovalis, Halodule uninervis and Syringodium isoetifolium.

Keywords: Environmental changes, diversity, seagrass condition.

Corresponding author:

Jl. Pasir Putih I Ancol Timur, Jakarta Utara 14430. Email: indarto62@gmail.com 


\section{PENDAHULUAN}

Lamun merupakan satu-satunya tumbuhan berbunga (Spermatophyta) yang mampu hidup secara penuh beradaptasi pada lingkungan laut dengan kadar salinitas rendah (perairan payau) hingga salinitas tinggi (halofitik). Lamun berpembuluh, berdaun, berimpang (rhizoma), berakar, dan berkembang biak secara generatif (biji) dan vegetatif (tunas). Rimpangnya merupakan batang yang beruas-ruas yang tumbuh terbenam dan menjalar dalam substrat berpasir, pasir-berlumpur, dan lumpur (Pham et al., 2006) namun berfungsi normal serta mampu melaksanakan daur generatif. Padang lamun yaitu tumbuhan lamun yang menutupi suatu area pesisir laut dangkal pada mintakat pasang surut intertidal maupun subtidal yang dapat terbentuk oleh satu spesies lamun atau lebih dengan kerapatan padat atau jarang. Ekosistem lamun merupakan suatu sistem ekologis yang di dalamnya terjadi hubungan timbal balik antara komponen abiotik berupa substrat dan air dengan komponen biotik berupa flora dan fauna (Hartog, 1970; Thomlinson, 1974; Philips \& Menez, 1988).

Secara ekologis, padang lamun memiliki peran penting bagi wilayah perairan pesisir. Peran tersebut di antaranya yaitu sebagai sumber utama produktivitas primer (penghasil bahan organik), habitat berbagai biota (360 spesies ikan dengan 60 spesies bernilai ekonomis tinggi, 117 spesies makroalga, 24 spesies moluska, 70 spesies krustasea, dan 45 spesies Echinodermata), substrat bagi biota penempel, tempat asuhan bagi larva ikan dan biota lain, sumber makanan bagi biota langka seperti duyung (Dugong dugon), penyu, dan kuda laut (Hippocampus sp.), tempat berlindung dan tempat pembesaran beberapa spesies biota dan krustasea komersial penting (Pioneer et al., 1989; Gray et al., 1996) serta untuk menyokong keanekaragaman jenis-jenis biota laut (Park \& Wildlife, 1999). Secara fisik, padang lamun dapat memerangkap sedimen dasar yang lunak dan memperlambat arus sepanjang pantai. Padang lamun juga mempunyai nilai ekonomis, yaitu sekitar Rp 21.014.756 pada jasa ekosistem lamun (Wawo et al., 2014) dan Rp 20.579.103/tahun per ha dari sektor pariwisata dan perikanan (Dirhamsyah, 2007). Peran lamun dalam skala luas yaitu menjaga kestabilan $\mathrm{pH}$ air laut, menyimpan karbon, dan memiliki konektivitas dengan ekosistem bakau dan terumbu karang. Padang lamun sangat efektif menyerap $\mathrm{CO}_{2}$ dengan serapan sebesar 1.867 ton $/ \mathrm{km}^{2}(48 \%)$ relatif lebih tinggi dibandingkan bakau sebesar 806 ton $/ \mathrm{km}^{2}(21 \%)$ dan karang sebesar 1.197 ton $/ \mathrm{km}^{2}$ (31\%) (Simamora, 2010). Karena perannya yang sangat kompleks, padang lamun dapat dikatakan sebagai salah satu ekosistem yang paling produktif di suatu perairan dan dikenal sebagai ekosistem laut yang penting (Fortes, 1990;
Thangaradjon et al., 2007).

Kegiatan pembangunan saat ini di Pulau Bintan khususnya penambangan pasir bouksit yang terus meningkat dapat berdampak terhadap pertumbuhan, perkembangan, dan kondisi padang lamun. Perubahan lingkungan yang disebabkan oleh kegiatan manusia (Short \& Wyllie-Echeverria, 1996; Duarte, 2002) di wilayah pesisir pantai yang terus-menerus dan lebih cepat daripada pemulihan pertumbuhan lamun, mempunyai kontribusi besar terhadap kerusakan padang lamun. Perencanaan tata guna lahan di wilayah pesisir pada dasarnya berhubungan langsung dengan masalah spasial seperti konflik pemanfaatan lahan dan kerusakan ekosistem (karang dan lamun) (Baja, 2012). Hasil penelitian oleh Asyiawati (2010) bahwa perubahan pemanfaatan lahan dari kawasan lindung menjadi lahan pertanian kering telah menurunkan kondisi ekosistem pesisir 11,23\% (20032008) di Teluk Ambon Maluku. Faktor lain penurunan kondisi lamun seperti kegiatan lalu lalang perahu nelayan yang tinggi juga berdampak negatif terhadap keberadaan padang lamun (Engeman et al., 2008). Oleh karena itu, kajian kondisi padang lamun di perairan timur pulau Bintan saat ini menjadi sangat penting dalam upaya menjaga dan melestarikan padang lamun khusunya di perairan timur pulau Bintan. Hal ini selaras dengan dukungan pemerintah setempat terkait dengan perlindungan padang lamun yaitu beberapa desa telah ditetapkan sebagai Kawasan Konservasi Padang Lamun (KKPL) yang termuat dalam Peraturan Desa Teluk Bakau, Kecamatan Gunung Kijang, Kabupaten Bintan No. 21 Tahun 2009 dan dikuatkan dengan Surat Keputusan Kepala Bupati Bintan No. 267/VI/2010,

\section{METODE PENELITIAN}

\section{Lokasi dan Waktu Kajian}

Karakteristik pesisir pantai Bintan Timur dicirikan dengan pantai berpasir sepanjang mulai dari Sungai Kawal sampai Berakit. Butiran pasir umumnya berupa mineral kalsit. Sepanjang pesisir timur pulau Bintan telah ditentukan stasiun pemantauan lamun secara 'porposive sampling sebanyak 12 staisun. Kegiatan penelitian dampak terhadap kondisi lamun di pesisir pantai Bintan Timur dilakukan pada Mei dan September (2015-2016). Lokasi penelitian, muara sungai dan stasiun pemantauan kondisi lamun seperti tersaji pada (Gambar 1).

\section{Penggunaan Lahan dan Debit Suspensi}

Analisa perubahan penggunaan lahan menggunakan data citra multispektral yaitu citra Landsat-5 (1990, 1995, dan 1999) dan Landsat-8 (2014 dan 2016). Dasar pemilihan rekaman data citra 


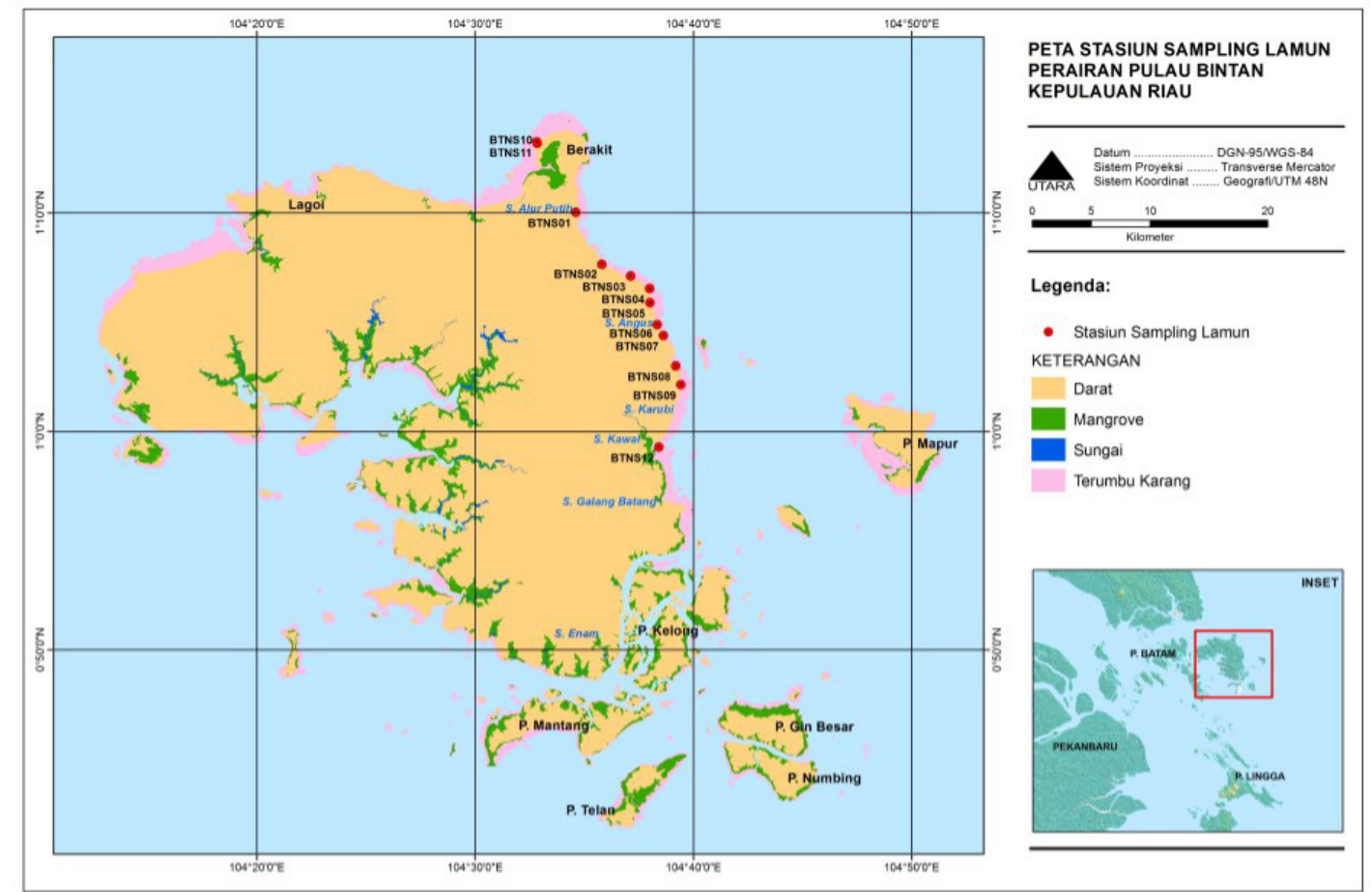

Gambar 1. Lokasi penelitian, nama muara sungai dan stasiun pemantauan kondisi lamun di perairan timur Pulau Bintan.

di Pulau Bintan yaitu data rekaman citra yang bebas dari tutupan awan atau minimal dengan tutupan awan. Rekaman data citra Landsat-5 dengan tutupan awan berkisar antara $5-10 \%$, sedangkan citra Landsat-8 berkisar antara $10-30 \%$. Klasifikasi penggunaan lahan dengan menggunakan metode 'supervised maximum likelihood'. Klasifikasi ini merupakan salah satu klasifikasi terbimbing yang secara parametrik umum dipergunakan untuk klasifikasi penutup/penggunaan lahan dengan citra penginderaan Jauh (Mukhaiyar, 2010). Penggunaan lahan diklasifikasi menjadi 8 kelas antara lain lahan terbangun, lahan terbuka, bakau, tubuh air, vegetasi: kerapatan rendah, sedang, dan tinggi serta lahan unclassified.

Data citra dengan tutupan awan cukup banyak diasumsikan sama dengan hasil interpretasi pada tahun berikutnya dengan tutupan awan relatif sedikit. Hal ini dilakukan untuk mengurangi kesalahan dalam penghitungan total luasan. Proses analisa data citra satelit dengan menggunakan perangkat lunak ENVI 5.1 dan proses final layout peta dengan menggunakan perangkat lunak ArcGIS versi 10.1.

Pengukuran dan pengambilan sampel air sungai (suspended load) dilakukan di beberapa muara sungai antara lain sungai Galang Batang, Kawal, Angus, Karubi dan sungai Alur Putih (Gambar 1). Pengukuran kecepatan aliran sungai dengan menggunakan current meter 'Reading Current Meter' seri SeaGuard Merk AA andera. Sampel air suspensi sungai diambil di setiap muara sungai dengan alat 'Nansent' disaat musim hujan dan air menuju surut. Sampel suspensi air disimpan dalam botol dan dilakukan analisa dengan penyaringan di lapangan dengan kertas milipore 46 $\mu \mathrm{m}$. Hasil penyarigan selanjutnya dilakukan pengeringan (oven) dan penimbangan di Laboratorium Geologi-P2O LIPI Jakarta.

\section{Keanekaragaman Spesies dan Kondisi Lamun}

Identifikasi keanekaragaman spesies lamun di suatu hamparan lamun dilakukan dengan cara sampling transek tegak lurus garis pantai ke arah tubir $100 \mathrm{~m}$ pada saat surut terendah. Lamun dalam bingkai berukuran $50 \times 50 \mathrm{~cm}^{2}$ lalu diidentifikasi dan dicatat spesiesnya dengan mengacu pada pedoman identifikasi lamun (McKenzie, 2003). Pada interval 10 $\mathrm{m}$ sepanjang transek kuadrat diletakkan, persentase tutupan lamun dalam bingkai tersebut diduga dengan mengacu pada panduan pemantauan padang lamun (Rahmawati et al., 2014).

Dalam penentuan kondisi padang lamun di Indonesia, saat ini belum ada standart penilaian yang secara jelas dapat digunakan. Referensi penentuan kondisi padang lamun dapat mengacu pada Keputusan (KMN-LH, 2004) tentang status dan kerusakan padang lamun berdasarkan persentase tutupan lamun, yaitu kategori sehat $(\geq 60 \%)$, kurang sehat $(30-59,9 \%)$, dan miskin $(<29,9 \%)$. Juga berdasarkan atas persentase tutupan lamun (Rahmawati et al., 2014) menentukan kondisi lamun, yaitu sangat padat $(76-100 \%)$, padat (51-75\%), cukup padat (26-50\%), dan jarang (0-25\%). 
Penentuan kondisi lamun dalam kajian ini mengacu pada (KMN-LH, 2004) dengan memodifikasi penamaan klasifikasi yaitu sehat menjadi baik $(\geq 60 \%)$, kurang sehat menjadi sedang (30-59,9\%), dan miskin menjadi jelek $(<29,9 \%)$.

\section{HASIL DAN PEMBAHASAN}

\section{Tutupan Lahan}

Kegiatan penambangan pasir bouksit dan alih fungsi lahan bervegetasi menjadi lahan terbuka terus meningkat. Hal ini telah mempercepat terjadinya sedimen transport permukaan. Pembukaan lahan terus menerus dapat meningkatkan kekeruhan dan laju sedimentasi di perairan pantai (Adriman et al., 2013). Berdasarkan analisa data citra diketahui perubahan penggunaan lahan seperti lahan terbuka yang semakin meningkat seperti disajikan dalam Tabel 1, 2 dan Gambar 2.

Dari Tabel 1, 2, dan Gambar 2, kecenderungan pengunaan lahan khususnya lahan yang terbuka (lahan tidak bervegetasi) selama 1990-2016 cenderung terus meningkat meskipun 1995 terjadi pelambatan dalam pembukaan lahan. Pada 1990-1995 luas lahan terbuka mengalami penurunan dengan laju $-805,6$ ha/tahun. Nilai luas lahan terbuka menurun dari $15.986,35$ ha

Tabel 1.

Hasil analisa luas penggunaan/tutupan lahan pada data citra landsat-5 dan Landsat-8 di wilayah Pulau Bintan

\begin{tabular}{llllll}
\hline Tipe Lahan & \multicolumn{5}{l}{ Luas Penggunaan/tutupan lahan (ha) } \\
\cline { 2 - 6 } & $\mathbf{1 9 9 0}$ & $\mathbf{1 9 9 5}$ & $\mathbf{1 9 9 9}$ & $\mathbf{2 0 1 4}$ & $\mathbf{2 0 1 6}$ \\
\hline Lahan Terbangun & $3.670,11$ & $9.199,69$ & $11.600,89$ & $10.030,57$ & $5.069,96$ \\
Lahan Terbuka & $15.986,35$ & $11.958,17$ & $19.793,83$ & $28.397,82$ & $39.499,63$ \\
Mangrove & $6.534,78$ & $5.558,80$ & $5.542,03$ & $5.589,09$ & $6.613,93$ \\
Tubuh Air & $1.171,87$ & $1.499,38$ & $1.783,53$ & $1.154,14$ & $1.037,23$ \\
Unclassified & $4.880,47$ & 856,60 & 302,78 & 101,59 & 57,92 \\
Vegetasi: & & & & & \\
Kerapatan Rendah & $35.722,28$ & $45.766,69$ & $44.330,61$ & $39.874,28$ & $24.055,66$ \\
Kerapatan Sedang & $23.884,37$ & $25.811,59$ & $17.453,96$ & $10.153,05$ & $19.649,19$ \\
Kerapatan Tinggi & $25.164,67$ & $16.363,98$ & $16.169,98$ & $21.654,07$ & $20.940,97$ \\
\hline
\end{tabular}

Tabel 2.

Kecenderungan lahan terbuka/ tidak bervegetasi di Pulau Bintan 1990-2016

\begin{tabular}{lll}
\hline Tahun & Lahan Terbuka (ha) & Rata-rata Trend (+/- ha/th) \\
\hline 1990 & $15.986,35$ & $-805,6$ \\
1995 & $11.958,17$ & $+1.958,9$ \\
1999 & $19.793,83$ & $+573,6$ \\
2014 & $28.397,82$ & $+5.550,9$ \\
2016 & $39.499,63$ & \\
\hline
\end{tabular}

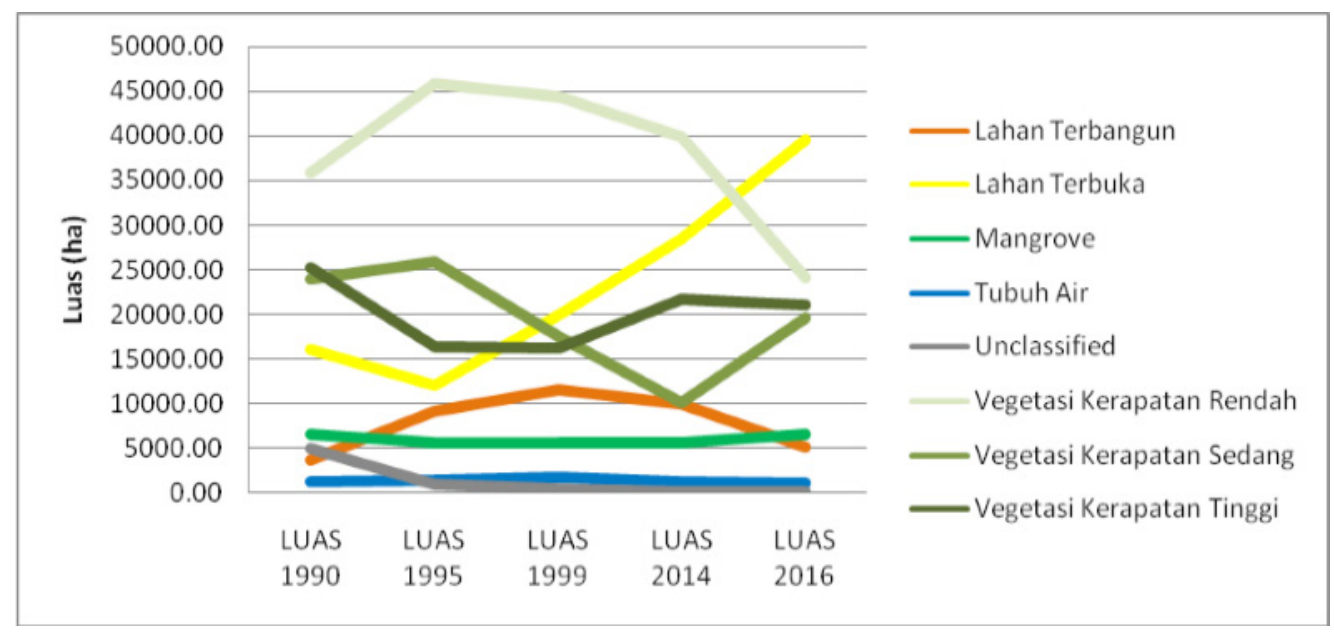

Gambar 2. Kecenderungan berbagai penggunaan lahan di Pulau Bintan 1990-2016. 
menjadi $11.958,17$ ha. Hal ini mempunyai arti bahwa selama lima tahun telah terjadi pentupan kembali lahan terbuka yang di interpretasikan karena tumbuhnya semak-semak atau tanaman liar. Dalam kurun waktu empat tahun kemudian 1995-1999 luas lahan terbuka meningkat tajam menjadi $19.793,83$ ha atau dengan laju $+1.958,92$ ha/tahun. Kondisi ini dapat diduga dan di interpretasikan bahwa telah terjadi perluasan lahan terbuka salah satunya untuk perkebunan kelapa sawit. Luas tutupan lahan terbuka mulai melambat selama 15 tahun yaitu $19.793,83$ ha (1999) menjadi $28.397,82$ ha (2014) menyusutnya luas lahan terbuka ini diduga karena perkebunan kelapa sawit mulai tumbuh. Hal ini sesuai dengan hasil interpretasi kerapatan tumbuhan dengan kerapatan tinggi terjadi pada 2014 (Tabel 1 dan 2). Luas lahan terbuka meningkat kembali secara signifikan mencapai $39.499,63$ ha (2016) dari $28.397,82$ ha (2014) menunjukkan bahwa kegiatan pembukaan lahan diduga untuk penambangan pasir sampai saat ini masih berlangsung dan mempunyai kecenderungan semakin cepat dengan laju $+5.550,9$ ha/tahun (Tabel 2). Perubahan luas penggunaan/ tutupan lahan terbuka di Pulau Bintan selama 19902016 secara umum mempunyai kecenderungan semakin meningkat hal ini tergambarkan pada citra landsat seperti tersaji dalam (Gambar 3).

Secara umum di Pulau Bintan telah terjadi peningkatan lahan yang tidak bervegetasi cukup signifikan. Berdarsarkan analisa rekaman data citra Landsat-7 (2003), Landsat-8 (2013) dan SPOT-5 (2014) juga terjadi di pesisir Bintan Timur yaitu perubahan luas lahan terbuka dengan percepatan $+153,8$ ha/tahun, lahan perkebunan $+373,8$ ha/tahun dan penyusutan padang rumput $-477,8$ ha/th (Tabel 3 ). Hasil analisa data citra Landsat dan SPOT secara spasial selama kurun waktu 11 tahun tersaji pada dalam Gambar 3. Perubahan lingkungan terjadi di perairan timur pulau Bintan dapat disebabkan oleh hasil pembukaan lahan di bagian atas (upland) melalui sedimen terlarut dari beberapa sungai yang bermuara di perairan.

Tabel 3.

Hasil analisa data citra Landsat 2003-2014 dan SPOT 2014 di pesisir timur Pulau Bintan

\begin{tabular}{llll}
\hline Land use & $\mathbf{2 0 0 3}(\mathbf{h a})$ & $\mathbf{2 0 1 4}(\mathbf{h a})$ & Trend (+/-) \\
\hline Semak & $9.821,34$ & $9.101,42$ & $-65,45$ ha/th \\
Perkebunan & 94,46 & $4.206,48$ & $+373,82 \mathrm{ha} / \mathrm{th}$ \\
Lahan terbuka & $2.718,44$ & $4.410,27$ & $+153,80 \mathrm{ha} / \mathrm{th}$ \\
Lahan terbangun & 916,73 & $1.089,54$ & $+15,71$ ha/th \\
Padang rumput & $7.786,63$ & $2.529,90$ & $-477,88 \mathrm{ha} / \mathrm{th}$ \\
\hline
\end{tabular}
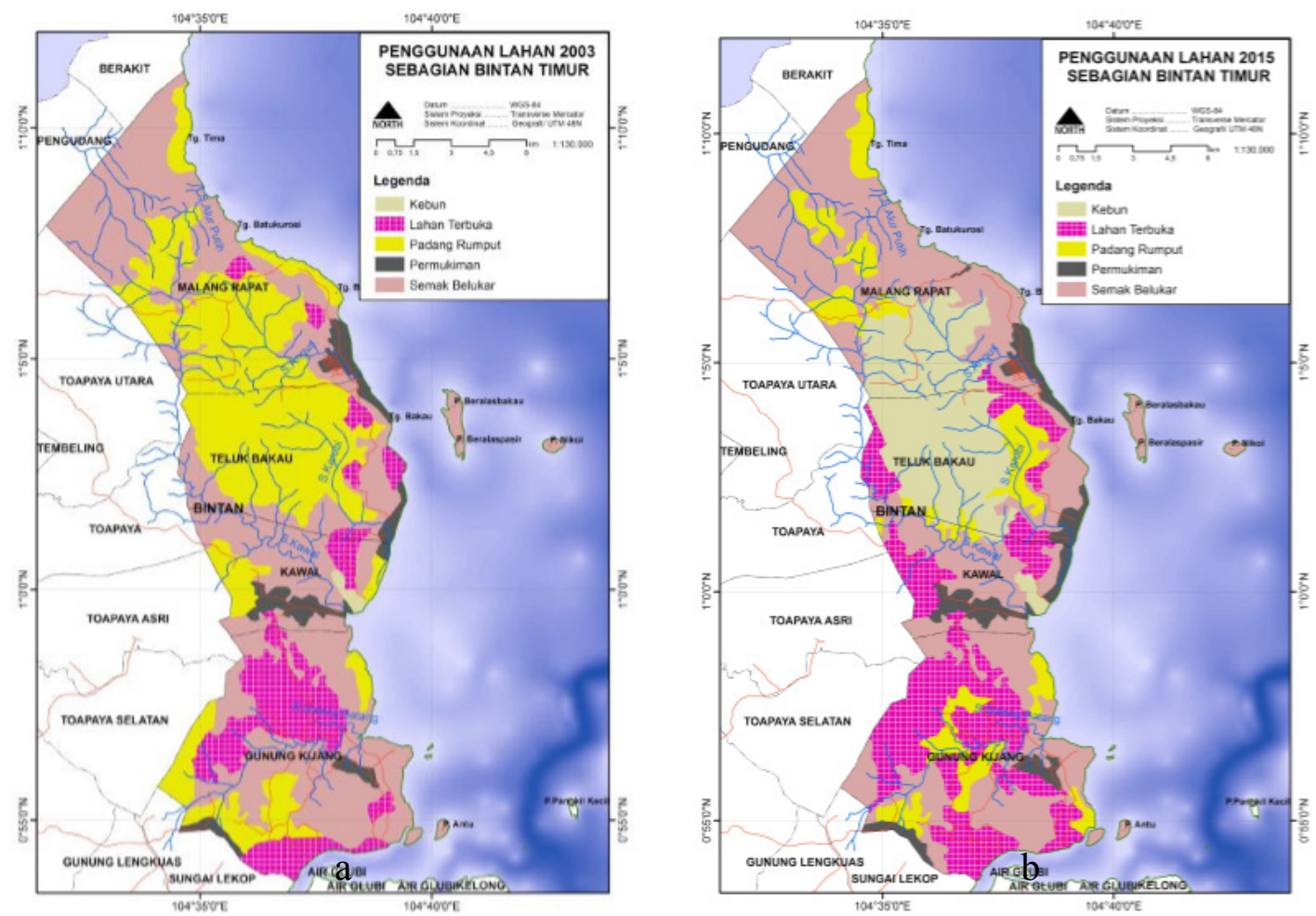

Gambar 3. Perubahan penggunaan lahan 2003 (a) dan 2014 (b) di pesisir timur Pulau Bintan. 


\section{Aliran Sungai Kawal dan Galang Batang}

Berdasarkan hasil penelusuran dan pengukuran langsung di lapangan terdapat dua sungai besar yang berkontribusi terhadap perubahan lingkungan perairan pantai yaitu Sungai Kawal di Kecamatan Kawal dan Sungai Galang Batang di Kecamatan Gunung Kijang. Sungai Kawal merupakan sungai dengan kedalaman $(2,82 \mathrm{~m})$ dengan lebar penampang sungai $41,99 \mathrm{~m}$, sedangkan sungai Galang Batang merupakan sungai dengan lebar $(240 \mathrm{~m})$ dengan kedalaman rata-rata 1,18 m (Supriyadi et al., 2015).

Hasil analisa penghitungan debit suspensi yang dilakukan di beberapa muara sungai bertepatan musim penghujan (Mei dan Desember) dapat dilihat dalam Tabel 4. Dari Tabel 4, diketahui debit suspensi atau beban Suspended Solid yang dibawa oleh aliran sungai Kawal pada musim hujan (Mei) yaitu 5.292 $\mathrm{mg} / \mathrm{dt}$ dan sungai Galang Batang yaitu $1.729 \mathrm{mg} / \mathrm{dt}$. Pada bulan September yang mewakili musim kemarau diketahui debit suspensi di sungai Kawal yaitu 4.619 $\mathrm{mg} / \mathrm{dt}$ dan sungai Galang Batang yaitu $1.568 \mathrm{mg} /$ dt. Selain dua sungai besar yang signifikan dalam mensuplai suspensi terlarut ke perairan, juga terhitung beberapa sungai kecil lainnya dengan debit suspensi bervariasi pada Mei antara lain sungai Angus $(29,33$ $\mathrm{mg} / \mathrm{dt})$, Alur Putih $(25,66 \mathrm{mg} / \mathrm{dt})$ dan Karubi $(196,23$ $\mathrm{mg} / \mathrm{dt}$ ) (Supriyadi et al., 2015).

Dengan diketahuinya besaran beban sedimen tersuspensi di muara sungai, dapat memberikan gambaran kontribusi dampak perubahan tutupan lahan yaitu lahan yang terbuka/tidak bervegetasi terhadap tingkat kekeruhan di perairan. Pola curah hujan di Pulau Bintan yaitu 'bimodal' dengan puncak curah hujan terjadi pada Mei dan Desember juga dapat memicu terhadap meningkatnya sedimen run-off yang selanjutnya berkontribusi besar terhadap kualitas perairan timur Pulau Bintan. Jika lahan terbuka terus meningkat, hal ini dapat berdampak serius terhadap pertumbuhan dan perkembangan lamun disekitar perairan muara sungai Kawal khususnya serta di perairan timur Pulau Bintan umumnya.

Dampak tingkat kekeruhan di perairan pantai yang berasal dari sungai Kawal dapat diperlihatkan hasil analsia tutupan lamun yang berada di sekitar muara sungai Kawal mulai dari stasiun BTNS08, BTNS09 dan BTNS12 kecenderungan persentase tutupan lamun atau kondisi lamun menurun (Gambar 1 dan Tabel 5). Kondisi lamun dengan persentase tutupan lebih baik seperti BTNS01, BTNS02, BTNS03, BTNS04, BTNS05 dan BTNS06 cenderung kurang terdampak oleh aliran sungai seperti sungai Angus, Alur Putih dan Karubi (Tabel 5).

Tabel 4.

Hasil analisa debit sedimen tersuspensi di beberapa sungai pesisir Pulau Bintan Mei (musim hujan) \& September (kemarau) 2015

\begin{tabular}{lllllll}
\hline No. & Sungai & Debit & \multicolumn{2}{c}{ TSS $\left(\mathbf{m g} / \mathbf{m}^{3}\right)$} & \multicolumn{2}{c}{ Debit Suspensi $(\mathbf{m g} / \mathbf{d t})$} \\
& & $\left(\mathbf{m}^{3} / \mathbf{d t}\right)$ & Hujan & Kering & Hujan & Kering \\
\hline 1 & Kawal & 46,061 & 114,9 & 100,3 & 5.292 & 4.619 \\
2 & Angus & 0,356 & 82,4 & - & 29,33 & - \\
3 & Alur Putih & 0,332 & 77,3 & - & 25,66 & - \\
4 & Galang Batang & 15,01 & 115,2 & 104,5 & 1.729 & $1.568,5$ \\
5 & Karubi & 2,545 & 77,1 & - & 196,23 & - \\
\hline
\end{tabular}

Tabel 5.

Hasil analisa kondisi lamun di perairan timur Pulau Bintan 2015-2016

\begin{tabular}{lllll}
\hline No. & Stasiun & Spesies & $\begin{array}{l}\text { Tutupan } \\
\text { lamun (\%) }\end{array}$ & Kondisi lamun \\
\hline 1 & BTNS01 & Th, Ea, Cr, Cs, Si, Ho, Hu 41,48 & sedang \\
2 & BTNS02 & Th, Cs, Si, Hu & 40,91 & sedang \\
3 & BTNS03 & Th, Ea, Cr, Cs, Si, Hu & 60,80 & seik \\
4 & BTNS04 & Th, Ea, Cs, Ho & 41,48 & sedang \\
5 & BTNS05 & Ea, Cr & 41,48 & sedang \\
6 & BTNS06 & Th, Ea, Cr, Cs, Hu & 58,52 & sedang \\
7 & BTNS07 & Th, Si & 18,18 & Jelek \\
8 & BTNS08 & Th, Ea & 44,32 & sedang \\
9 & BTNS09 & Th, Ea, Cr & 38,64 & sedang \\
10 & BTNS10 & Th, Ea, Cr, Ho, Hu & 46,02 & sedang \\
11 & BTNS11 & Th, Ea, Cr, Ho, Hu & 22,32 & Jelek \\
12 & BTNS12 & Th, Ea, Cr, Ho, Hu & 36,25 & sedang \\
\hline \multicolumn{5}{c}{ Rata-rata } \\
\hline
\end{tabular}




\section{Keanekaragaman Spesies}

Berdasarkan hasil identifikasi keanekaragaman spesies lamun di perairan timur Pulau Bintan ditemukan 7 spesies antara lain Enhalus acoroides (Ea), Cynodocea rotundata (Cr), Cymodocea serrulata (Cs), Halophila ovalis (Ho), Halodule uninervis $(\mathrm{Hu})$, Syringodium iseotifolium ( $\mathrm{Si})$, dan Thalassia hemprichii (Th). Tujuh spesies yang ditemukan saat ini lebih sedikit dibandingkan dengan 10 spesies yang pernah ditemukan pada penelitian terdahulu dengan metode 'stop and go' (Kuriandewa \& Supriyadi, 2006). Tiga spesies belum ditemukan dan diduga berada di lokasi perairan Pulau Bintan yaitu Thalassodendron ciliatum (Tc), Halophila spinulosa (Hs), dan Halodule pinifolia (Hp). Perbedaan jumlah spesies yang ditemukan saat ini lebih sedikit dibandingkan dengan temuan sebelumnya. Hal ini karena metode yang dipergunakan pada 2006 yaitu 'stop and go' dengan menggunakan sarana perahu yang dapat menjangkau sampai batas tubir yang memungkinkan tiga spesies lainnya ditemukan, sedangkan metode kajian saat ini mengacu pada panduan pemantauan padang lamun (Rahmawati et al., 2014) yaitu transek tegak lurus ke arah laut sampai 100 meter dan pada saat air laut menuju surut.

Dari 7 spesies hanya dua spesies sering ditemukan di perairan timur Pulau Bintan yaitu Enhalus acoroides, dan Thalassia hemprichii, empat spesies jarang ditemukan Halodule uninervis, Cymodocea rotundata, Cymodocea serrulata, Halophila ovalis, dan satu spesies sangat jarang ditemukan yaitu Syiringodium isoetifolium (Gambar 4). Jumlah spesies lamun di perairan Indonesia ada 12 dari 15 yang pernah ditemukan adapun tiga spesies yang langka ditemukan yaitu Halophila sulawesi endemik di Sulawesi Selatan (Kuo, 2007), Halophila beccarii dan Ruppia maritima tersimpan di herbarium Bogor dan Ancol-Jakarta serta Pasir Putih-Jawa Timur, namun kedua spesies tersebut keterangan tanggal, nama lokasi dan penemu tidak tercatat dengan baik.

\section{Luas Padang Lamun}

Luas padang lamun khususnya di perairan timur Pulau Bintan yaitu 2.598 ha (Kuriandewa \& Supriyadi, 2006). Berdasarkan data luas padang lamun saat ini yang memperlihatkan luas padang lamun menyusut. Menurut Indayani (2016), berdasarkan analisa data citra SPOT-5 rekaman 2014 bahwa habitat dasar perairan dangkal yang ada di perairan timur Pulau Bintan didominasi oleh pasir $29,98 \%$, lamun $22,04 \%$, karang hidup 16,13\%, makro alga-karang hidup 12,16 $\%$, makro alga $11,61 \%$ dan karang mati-makro alga $8,16 \%$ dengan akurasi $62 \%$. Berdasarkan hasil analsia data citra SPOT sebaran habitat lamun hanya 22,04 \% dibandingkan dengan tutupan habitat dangkal lainnya artinya menunjukkan sudah mengalami penurunan luasan padang lamun di perairan timur Pulau Bintan.

\section{Kondisi Lamun}

Perubahan pemanfaatan lahan darat hubungannya degan kondisi ekosistem pesisir di Teluk Ambon menunjukkan penurunana rata-rata $11,23 \%$ (2003-2008) yang disebabkan oleh perubahan tutupan kawasan lindung menjadi kawasan campuran dan lahan pertanian kering (Asyiawati, 2010). Perencanaan tata guna lahan yang tidak dilakukan secara terpadu (integrated) pada dasarnya berhubungan secara langsung terhadap permasalahan spasial wilayah pesisir (Baja, 2012). Kondisi atau kesehatan lamun salah satunya dapat ditentukan melalui persentase tutupan lamunnya. Berdasarkan analisa persentase tutupan lamun dari 12 transek tegak lurus pantai,

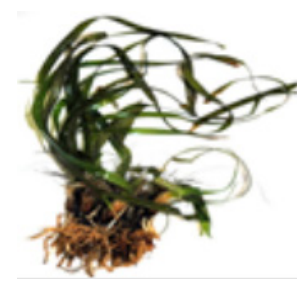

Ea

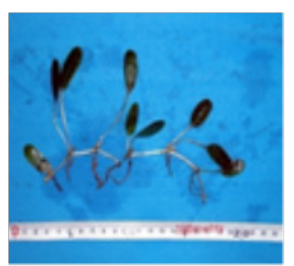

Ho

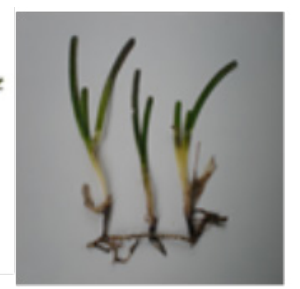

Th

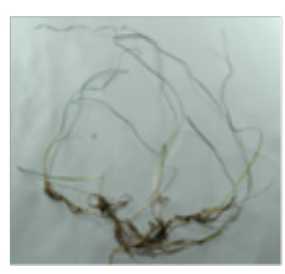

$\mathrm{Hp}^{*}$

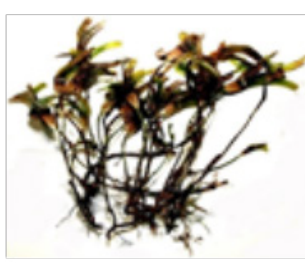

$\mathrm{Tc}^{*}$

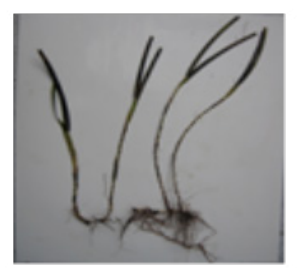

$\mathrm{Hu}$

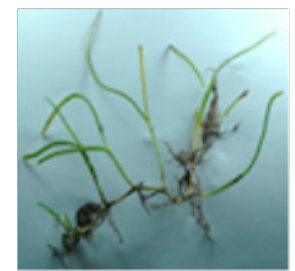

$\mathrm{Si}$

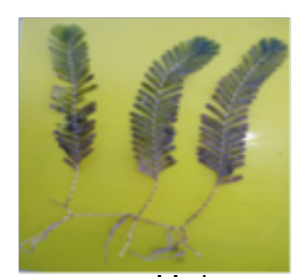

$\mathrm{Hs}^{*}$

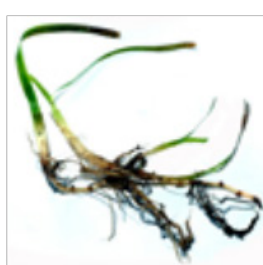

$\mathrm{Cr}$

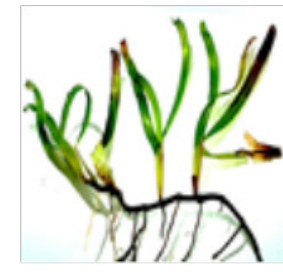

Cs

Gambar 4. Keanekaragaman spesies lamun di perairan timur Pulau Bintan "belum ditemukan. 
diketahui kondisi lamun di perairan timur Pulau Bintan dapat dikategorikan 'baik' hanya di stasiun BTNS03, kategori 'sedang' hampir ditemukan di seluruh perairan timur Pulau Bintan, dan kategori 'jelek' ditemukan di BTNS07 dan BTNS11 (Tabel 5). Kondisi lamun di perairan timur Bintan dari BTNS08, BTNS09 dan BTNS12 cenderung menurun dengan persentase tutupan masing masing 44,32\%, 38,64\% dan 36,25\%. Berdasarkan hasil analisa citra (Gambar 3b), Daerah Aliran Sungai (DAS) Kawal dengan tutupan lahan sebagian besar perkebunan, lahan terbuka dan semak belukar, telah berdampak terhadap penururnan tutupan lamun. Hal ini berbeda dengan DAS muara sungai lainnya seperti Karubi, Angus dan Alur putih umumnya tutupan lahannya masih berupa semak belukar dan kebun, sehingga dampak terhadap kondisi lamun masih rendah.

Secara umum kondisi lamun di perairan timur Pulau Bintan pada tahun 2015 rata-rata persentase tutupan lamun $41 \%$ lebih rendah jika dibandingkan dengan persentase tutupan lamun 46 \% (Kuriandewa \& Supriyadi, 2006). Berdasarkan gambar 3b bahwa tutupan lahan terbuka pada lahan bagian atas untuk aktifitas penambangan pasir bouksit, peruntukan perkebunan yang masih terus berlangsung khususnya DAS Kawal dan penurunan persentase tutupan lamun sejak 2006-2015 memberikan gambaran bahwa perubahan tutupan lahan di bagian atas telah mengancam kondisi lamun di perairan timur Pulau Bintan.

\section{KESIMPULAN DAN SARAN}

\section{Kesimpulan}

Pembukaan lahan menjadi lahan terbuka dan perkebunan dan semak belukar pada DAS Kawal telah memberikan dampak menurunnya kondisi lamun di perairan timur Pulau Bintan. DAS sungai lainnya Karubi, Angus dan Alur putih dengan tutupan lahan yaitu semak belukar dan perkebunan relatif kurang berdampak terhadap kondisi lamun. Penurunan kondisi lamun ditunjukkan dengan persentase tutupan lamun yaitu 46 \% (2006) dan $41 \%$ (2015).

Dalam penelitian ini ditemukan tujuh spesies lamun, antara lain Enhalus acoroides, Thalassia hemprichii, Cymodocea rotundata, Cymodocea serrulata, Halophila ovalis, Halodule uninervis dan Syringodium isoetifolium.

\section{Saran}

Pengawasan terhadap kegiatan penambangan pasir, alih fungsi lahan perlu mendapat pengawasan secara ketat, oleh pemerintah setempat, karena data memperlihatkan lahan terbuka mempunyai kecenderungan terus meningkat.

Perlu dilakukan kajian mendalam terkait dengan penggunaan alat pukat siput gonggong yang diduga jenis alat tangkap bersifat merusak habitat padang lamun.

Pengelolaan padang lamun yang pernah dicapai oleh LIPI salah satunya di Pulau Bintan, Kepulauan Riau tahun 2007-2009 seyogyanya terus dipertahankan dan diupayakan melalui pengelolaan padang lamun berbasis pemberdayaan masyarakat.

Perlunya melibatkan stakeholder dalam pengelolaan padang lamun yaitu mendorong masyarakat dan pemangku kepentingan. Upaya menyelamatkan padang lamun dengan pengawasan terhadap kegiatan penambangan pasir dan alih pembukaan lahan serta penggunaan alat pukat "siput gonggong". Jika langkah langkah penyelamatan padang lamun tidak diupayakan, maka ekosistem padang lamun akan hilang sama artinya sumber daya perikanana juga akan berkurang.

\section{PERSANTUNAN}

Penelitian ini merupakan bagian dari kegiatan Research Agenda Coremap-CTI III dan mendapat pembiayaan selama dua tahun (2015-2016). Kami mengucapkan banyak terima kasih kepada Drs. Susetiono, M.Sc. dan Prof. Dr. Suharsono, M.Sc. selaku koordinator Coremap-CTI III (2015-2019) yang telah mempercayakan kami untuk melakukan kegiatan penelitian di perairan timur Pulau Bintan. Kami mengucapkan banyak terima kasih kepada Kasih Anggraini, Jatmiko Irianto, dan Suci Lastrini yang telah membantu dalam membuat peta, pengukuran dan analisa di Laboratorium Geologi P2O-LIPI Jakarta serta rekan rekan lainnya dalam tim Research Agenda 2015-2016.

\section{DAFTAR PUSTAKA}

Adriman, A., Purbayanto, A., Budiharso, S. \& Damar, A. (2013). Pengaruh sedimentasi terhadap terumbu karang di Kawasan Konservasi Laut Daerah Bintan Timur Kepulauan Riau. Berkala Perikanan Terubuk, 41(1): 90-101.

Asyiawati, Y. (2010). Pengaruh Pemanfaatan Lahan Terhadap Ekosistem Pesisir di Kawasan Teluk Ambon. Jurnal Perencanaan Wilayah dan Kota, $10(2): 1-5$

Baja, S. (2012). Perencanaan Tata Guna Lahan dalam Pengembangan Wilayah Pendekatan Spasial \& Aplikasinya. Penerbit Andi. Yogyakarta. 378 hal. ISBN : 9780792931921. 
Dirhamsyah. (2007). An economic valuation of seagrass ecosystems in East Bintan, Riau Archipelago, Indonesia. Oseanologi dan Limnologi di Indonesia, (33): 257-270.

Duarte, C.M. (2002). The future of seagrass meadows. Environ. Conserv., (29): 192-206.

Engeman, R.M., Dugnesnel, J.A., Cowan, E.M., Smith, H.T., Shwiff, S.A. \& Karlin, M. (2008). Assessing Boat damage to Seagrass Bed habitat in a Florida Park Fram a Bioeconomic prospective. Jurnal of Coastal Research, 24(2): 527-532.

Fortes, M.D. (1990). Seagrass: A Resources unknown in the ASEAN region. United State Coastal Resources Management Project. Education Series No. 646 p.

Gray, C.A., McElligoot, D. J. \& Chick, R. C. (1996). Intra and inter estuary differences in a assemblages of fish associated with shallow seagrass and bare sand. Marine Freshwater Res., (47): 723-735.

Hartog, D. (1970). The seagrass of the world. North Holand Publishing Company. Amsterdam, London, $271 \mathrm{pp}$.

Indayani, A.B. (2016). Pemetaan Habitat Dasar Perairan Dangkal Menggunakan Citra Spot-5 Di Pesisir Bintan Timur Kepulauan Riau. Skripsi Sarjana, Fakultas Perikanan dan Ilmu Kelautan, Departemen IImu dan Teknologi Kelautan,Institut Pertanian Bogor, Indonesia. 46 hal.

Kementrian Negara-Lingkungan Hidup (KMN-LH). (2004). Keputusan Menteri Negara Lingkungan Hidup No. 200 Tahun 2004 Tentang Kriteria Baku Kerusakan dan Pedoman Penentuan Status Padang Lamun, 16 hal.

Kuo, J. (2007). A New Monoecious seagrass Halophila sulawesii (Hydrocharitaceae) from Indonesia, Aquatic Botany. (in press). Available online at:www.cmca.uwa.edu.au/staff_pages/johnk-23k.

Kuriandewa, T. \& Supriyadi, I.H. (2006). Seagrass mapping in East Bintan coastal area Riau archipelago Indonesia. Coastal Marine Science, 30 (1), 154-161.

McKenzie, L.J. (2003). Draft guideline for the rapid assessment of seagrass habitat in the western Pasific (QFS, NFC, Cairns). Marine Plant Ecology Group, QDPI, Northern Fisheries Centre, Cairn: 43 pp.
Mukhaiyar, R. (2010) Klasifikasi Penggunaan Lahan Dari Data Remote Sensing. Journal Teknologi Informasi dan Pendidikan, 2(1) : ISSN : 20864981.

Pham, M.T., Nguyen, H.D., Nguyen, X.H. \& Nguyen, T.L. (2006). Study on the variation of seagrass population in coastal waters of Khanh Hoa Province, Vietnam. Coastal Marine science, 30 (1):167-173.

Philips, R.C. \& Menez, E.G. (1988). Seagrass. Smithsonian Institution Press. Washington D.C. $104 \mathrm{p}$.

Pioneer, I.R., Walker, D.I., \& Coles, R.G. (1989). Regional studier seagrass of tropical Australia. Biology of Seagrass: a treatise on the Biology of seagrass with special reference to the Australian region. A.W.D. Larkum, A.J.McComb \& S.A. Shepard (Eds.). Elsevier Amsterdam, 279-303 pp.

Rahmawati, S., Irawan, A., Supriyadi, I.H. \& Azkab, M.H. (2014). Panduan pemantauan padang lamun. Malikusworo Hutomo dan Anugerah Nontji (editor). CRITC, COREMAP-LIPI. Jakarta, 37 halaman.

Short, F.T. \& Wyllie-Echeverria, S. (1996). Natural and human-induced distribution of segrass. Environ Conrsev., (23):17-27.

Simamora, A.P. (2010). Look to sea as potensial carbon sink. http://Batavia.co.id/node/100393.Govt.

Supriyadi, I.H., Tarigan, S., Rositasari, R., Nurhayati, Muchtar, M., Kiswara, W., Iswari, M.Y. \& Purwandana, E. (2015). Kajian dampak dan adaptasi gejala perubahan iklim global: Studi kasus Pulau Bintan Timur-Kepulauan Riau. Laporan Akhir. Coremap-CTI III, Pusat Penelitian Oseanografi-LIPI. 55 hal (unpublished).

Texas Park \& Wildlife. (1999). Seagrass conservation plan for Texas. Resources Protection Division. Austin TX. 79 pp.

Thangaradjon, T., Sridhar, R., Senthilkumar, S. \& Kananu, S. (2007). Seagrass resources assessment in the Mandapam coast of the Gulf of Mannar Biosphere reserve, India. Applied ecology and environmental research. 6(1): 139146. Available at: http://www.ecology.uni-corvinus. hu.

Thomlinson, P.B. (1974). Vegetation morphology and meristem dependence as the foundation of productivity in seagrass. Aquaculture, (4),107- 
130.

Wawo, M., Adrianto, L., Bengen, D.G. \& Wardianto, Y. (2014). Valuation of seagrass ecosystem services in Kotania Bay Marine Natural Tourism Park, West Seram, Indonesia. Asian Journal of Scientific Research. \&:591-600. DOI: 10.3923/ ajsr.2014.591.600. URL:http://scialert.net/abstra ct/?doi:ajsr.2014.591.600. 